\title{
OPTIMIZING SOME DIFFERENT OPERATING PARAMETERS AFFECTING THE PERFORMANCE OF COMPOST TROMMEL SCREEN
}

\author{
Morad, M. M.*， H. A. El-Maghawry** and K. I. Wasfy ** \\ ABSTRACT
}

Experiments were carried out to evaluate the performance of a trommel screen for compost cleaning to increase product quality. Theoretical analysis was conducted for optimizing sieve speed and sieve inclination angle. The machine performance was studied as a function of change in material feed rate, screen opening size and compost moisture content. Performance evaluation of the trommel screen was carried out in terms of machine productivity, separating efficiency, compost losses, cleaning efficiency, required power, energy requirements and criterion cost. The experimental results reveal that the performance of the trommel screen during compost cleaning was in the optimum region under the following conditions:

- Operate the trommel screen at a sieve speed of $30 \mathrm{rpm}(2.5 \mathrm{~m} / \mathrm{s})$.

- The slope angle of the cylindrical sieve on the horizontal plane

(sieve inclination angle) should be lower than 27 degrees.

- The screen opening size should be of about $13 \mathrm{~mm}$.

- Clean compost at a moisture content of about $40 \%$.

- Operate the trommel screen at an average feed rate of $10 \mathrm{Mg} / \mathrm{h}$.

\section{INTRODUCTION}

$\mathrm{F}$ Tield crop residues are considered one of the most critical problems which face the Egyptian farmers. Accumulation of these residues in large quantities results not only in deterioration of the environment but also in a loss of potentially valuable material.

Manuring with these residues through composting is a promising route, especially with the increase in fertilizer price. Composting is the biological reduction of organic wastes to humus. The good composting structure depends on the correct mixing and turning of materials as well as, after maturity the correct screening of the produced compost.

\footnotetext{
* Prof. and Head of Agric. Eng. Dept., Fac. of Agric., Zagazig Univ. ** Lecturer of Agric. Eng., Fac. of Agric., Zagazig Univ.
} 
Screening improves the quality of the produced compost for sale or use by removing unwanted objects such as rocks, metals, clumps, and other trash. Klenin et al. (1985) mentioned that cleaning machines which separate the principle product from coarse impurities are known as wild oat separators (cylindrical screens). The working of the cylindrical screens involves the following operations: picking up small particles of the product by its cells, lifting the particles and throwing them into the receiver troughs. These operations are governed by the kinematics operating conditions of the machine and its geometric parameters. They added that sieves are selected according to their function. Various types of manufactured sieves are: sieves to separate ears and other impurities from grain, fine mesh sieves to shift fine impurities and grading sieves to separate grain into various fractions of different thickness or length. Robert et al. (1992) stated that when choosing screens, the important characteristics to consider are the screen opening size, capacity, effectiveness, cost, and susceptibility to blinding. For screening compost, the screen openings should be 0.25 to 0.5 inch $(0.63$ to $1.27 \mathrm{~cm})$, depending upon the material to be separated out and the end use for the compost. Smaller openings provide better separation but, for a given screen, reduce the capacity and increase the chances of blinding. The screen effectiveness decreased when particles larger than desired pass through the screen. Both effectiveness and capacity are influenced by the material feed rate as well as the screen opening size. Screens perform better with dryer material. To screen compost without excessive blinding, the moisture content should be less than $50 \%$ and it is preferably less than $45 \%$. William (2000) stated that the acceptable quantities of foreign matter in compost have been a subject of some debate, but generally there is greater agreement on these standards. Normally, stones are distinguished from non-decomposable "foreign matter" which includes glass, plastic and metal. The limits pertain to a percentage at a specific screen size. He classified foreign matter in compost into two parts: Stones \% of dry weight and Man-Made Foreign Matter (glass, plastic, metal), as \% of dry weight. Page et al. (2005) determined whether passing compost through a ball screen, an $18.75 \mathrm{~mm}$ trommel screen, or twice passing through an $18.75 \mathrm{~mm}$ of trommel screen lead to the lowest levels of foreign matter (undesirable material remaining 
in the final product) in the municipal solid waste compost. They found that the overall percentage of foreign matter ranged from $1.8 \%$ for the ball screen, to $2.72 \%$ for one pass with a trommel screen, and $1.75 \%$ for two passes with the trommel screen. Therefore, processing with the ball screener or two passes with the trommel screener created compost with a lower percentage of foreign matter. Mariam et al. (2010) carried out theoretical analysis to design and construct a local compost screening unit to achieve maximum cleaning efficiency. Theoretical analysis was conducted to estimate optimum sieve speed, optimum screen opening size and optimum sieve inclination angle. Maximum required power was estimated in order to provide the machine with the suitable source of power. The machine shaft was designed so as to save it from over loads and the high stresses. They concluded that the local compost screening unit is preferred to be constructed under sieve speed lower than $43 \mathrm{rpm}$, slope angle of the cylindrical sieve on the horizontal plane lower than 27 degrees, motor power required for screening compost must be not less than $3.68 \mathrm{~kW}(5 \mathrm{hp})$ and the machine shaft must be designed at a $70 \mathrm{~mm}$ diameter. Mariam et al. (2011) carried out experiments to manufacture and evaluate the performance of a small scale screening unit suitable for compost cleaning. The machine performance was studied as a function of change in material feed rate, sieve speed, sieve inclination angle and compost moisture content. Performance evaluation of the manufactured machine was carried out in terms of machine productivity, separating efficiency compost losses, cleaning efficiency, required power, energy requirements and criterion cost. They revealed that compost losses as well as criterion costs were minimum while separating and cleaning efficiencies were maximum under the following conditions: Operate the manufactured machine at a sieve speed of between 30 to $40 \mathrm{rpm}$ $(1.57$ to $2.1 \mathrm{~m} / \mathrm{s})$ with a sieve inclination angle of between 10 to 15 degrees, Clean compost at a moisture content of about $40 \%$ and operate the manufactured machine at a feed rate of $4.5 \mathrm{Mg} / \mathrm{h}$.

There are many factors that control the performance of compost cleaning machine. These factors can be divided into two sections: machine and material. Machine variables include sieve speed, sieve inclination angle, screen opening size and feeding rate. Moreover, material variables such as 
compost moisture content and degree of compost maturity are considered critical factors. The mentioned factors affect directly on the compost losses, efficiency, productivity, energy and cost requirements.

\section{So, the objectives of this study are to:}

- Utilize an imported trommel screen for cleaning compost to increase product quality.

- Optimize some different operating parameters (material feed rate, sieve speed, screen opening size, sieve inclination angle and compost moisture content) affecting the performance of the trommel screen.

- Evaluate the trommel screen performance from the economic point of view.

\section{MATERIALS AND METHODS}

Experiments were carried out through years of 2012 and 2013 at Super Bio Company for Organic Fertilizers, El-Senbelawen farm, Dakahlia Governorate, Egypt in order to evaluate the performance of a trommel screen with the purpose of cleaning compost.

\section{Materials}

\subsection{Compost}

Crop residues (especially rice straw) were used as a raw material for producing compost. Poultry and live-stock manure were also used to accelerate composting process. Added to that finished compost was used as a supply of microorganisms. Crop residues were formed in piles. Piles were then mixed and turned. Turning mixes the materials, rebuilds the porosity of the windrow, and releases trapped heat, water vapor and gasses. Turning exposes all material equally to the air at the surface and to the high temperatures inside the windrow. So, piles were turned four times per month for four months till maturity as recommended by Morad et al. (2008).

\subsection{The Trommel Screen}

A trommel screen was used for cleaning compost. The trommel screen consists mainly of screening device, transmission system and machine frame, as shown in Fig. (1).

\subsubsection{The screening device}

The screening device separates the principle product (clean compost) from coarse impurities and un-composted material. 

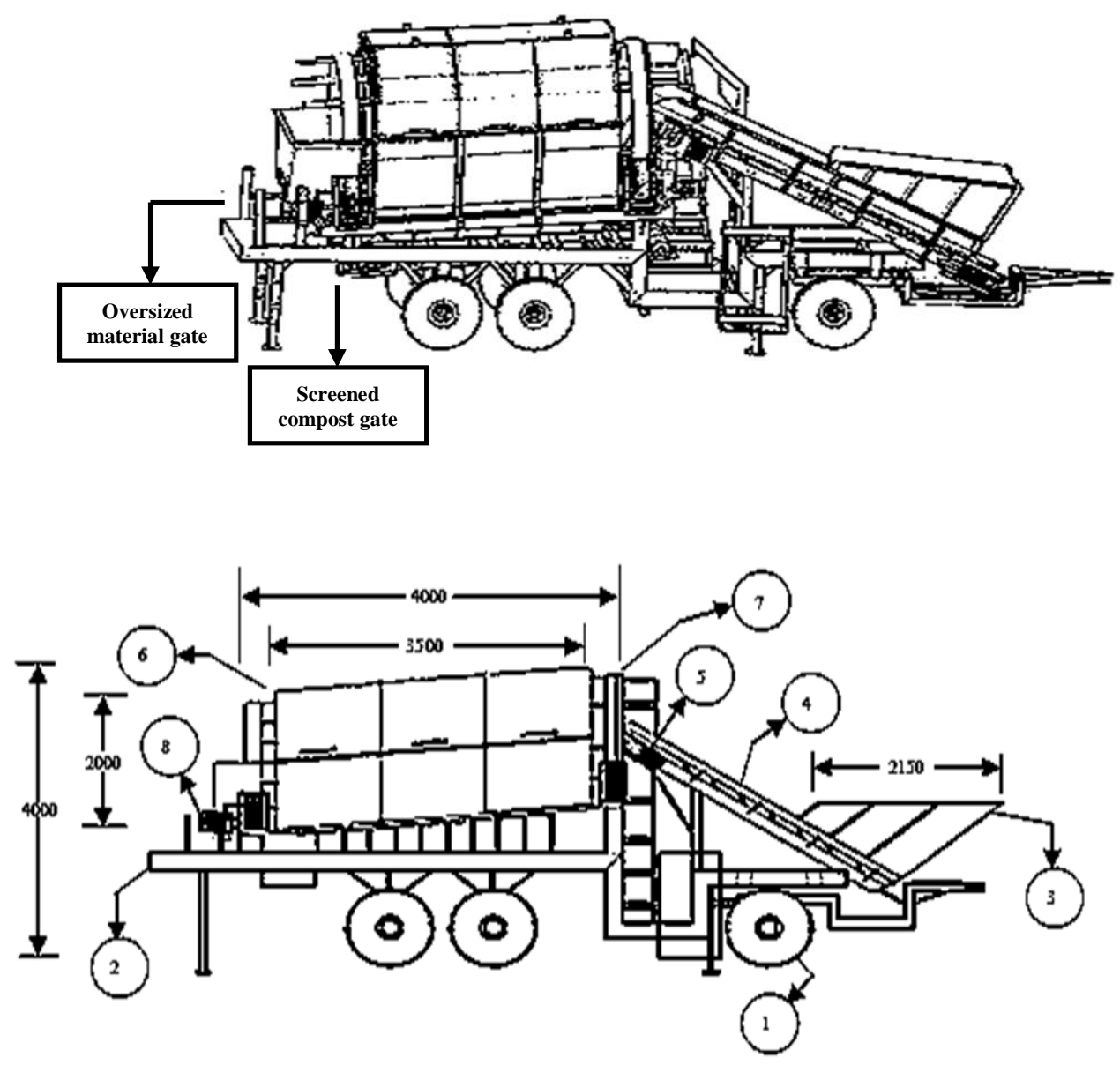

All dimensions in mm.

\begin{tabular}{|c|l|c|l|}
\hline No. & Part name & No. & Part name \\
\hline $\mathbf{1}$ & Machine wheels & $\mathbf{5}$ & Feeding device motor \\
\hline $\mathbf{2}$ & Frame & $\mathbf{6}$ & Cleaning unit cover \\
\hline $\mathbf{3}$ & Feeding unit & $\mathbf{7}$ & Cleaning sieve \\
\hline $\mathbf{4}$ & Feeding belt & $\mathbf{8}$ & Cleaning device motor \\
\hline
\end{tabular}

Fig. (1): Compost trommel screen

The screening device consists mainly of cleaning unit and feeding unit. 
1.2.1.1. The cleaning unit: The cleaning unit consists of four rotating wheels, a cleaning drum, a drum cover and a power source.

- The rotating wheels are made of rubber with $25 \mathrm{~mm}$ diameter. The rotating wheels are supported by four bearings. The rotating wheels are operated by means of pulley ( $35 \mathrm{~cm}$ diameter) and belt powered from the electric motor.

- The cleaning drum is supported on the rotating wheels so as to take its motion. The cleaning drum was manufactured from iron sheet of $8 \mathrm{~mm}$ thickness. The cleaning drum length is $400 \mathrm{~cm}$ while its diameter is $160 \mathrm{~cm}$. The cleaning drum consists of two parts. The first part is $350 \mathrm{~cm}$ in length perforated with round holes to allow clean compost to be separated and passing through the holes and collected from the out let of the screened compost, while the second part is $50 \mathrm{~cm}$ in length without holes to collect both impurities and un composted material to be delivered from the out let of the un wanted materials (oversized materials). The drum is also provided by screw bar to be tilted relating to the horizontal axis with an inclination angle.

- The drum cover is fixed around the cleaning drum and has a gate from below to deliver the screened compost through it and at the same time prevent delivering screened compost from the sides. The drum cover was manufactured from iron sheet of $4 \mathrm{~mm}$ thickness while its diameter is $200 \mathrm{~cm}$.

- The cleaning unit power source: The cleaning unit was powered by an electric motor $7.35 \mathrm{~kW}(10 \mathrm{hp})$ at a rated speed of $1450 \mathrm{rpm}$.

1.2.1.2. The feeding unit: The feeding unit is used to control the compost feeding rate passing to the cleaning unit. The feeding unit consists mainly of the conveyor flat belt, drive and driven pulleys.

- The conveyor flat belt with dimensions of $300 \mathrm{~cm}$ in length, $65 \mathrm{~cm}$ in width and $4 \mathrm{~mm}$ in thickness was constructed on drive and driven pulleys. The total length of the conveyor flat belt is $8.5 \mathrm{~m}$.

- The drive pulley is fixed at a height of $185 \mathrm{~cm}$ from the front side.

- The driven pulley is fixed at a height of $125 \mathrm{~cm}$ from the back side. The longitudinal distance between the front and the back sides is $273 \mathrm{~cm}$. This shape makes the oblique angle with horizontal at about 20 degrees. 
- The feeding unit power source: The feeding device was powered by an electric motor $2.21 \mathrm{~kW}(3 \mathrm{hp})$ at a rated speed of $1450 \mathrm{rpm}$.

\subsubsection{The transmission system:}

The rotating wheels of the cleaning unit are operated by means of machine pulley $(35 \mathrm{~cm}$ diameter) and belt powered from the electric motor pulley (10 cm diameter). The power is transmitted from the motor pulley to the rotating wheels with different speed ratios.

The feeding unit is operated by means of drive pulley $(32 \mathrm{~cm}$ diameter and $70 \mathrm{~cm}$ width) and belt powered from the electric motor pulley $(10 \mathrm{~cm}$ diameter). The power is transmitted from the motor pulley to the drive pulley with different speed ratios.

1.2.3. The trommel frame: The trommel frame carries all the machine parts, it is made of steel $\mathrm{L}$ section of $16 \mathrm{~mm}$ thickness. The frame is carried on four legs made of the same steel, two legs on each side and six rubber wheels (four wheels under the cleaning unit and two wheels under the feeding unit).

\section{Methods}

Experiments were carried out to evaluate the performance of the trommel screen to optimize the values of the main operating parameters during compost cleaning.

\subsection{Adjustment of Sieve Speed}

A cylindrical sieve is used to remove both impurities and un composted residues adhering to compost. The compost is delivered from one end of the rotating cylindrical sieve (inclined or horizontal). Then the compost tries to reach the other end of the cylinder. The work of the cylindrical sieve involves the following operations: picking up small particles of the material by its cells, lifting the particles and throwing them into the receiver trough. The compost mass in the cylindrical sieve is set in motion when the sieve begins to move. The particles next to the cells are carried in the direction of rotation of the cylinder because of friction at the cell surfaces (Klenin et al. 1985).

During this action, particles located at the lower portion of the cylinder are lifted upward by the screen surface to some height after which they are again lifted along with it and slide down. They gradually move toward the opposite end of the cylinder. The particles are in contact with only a 
part of the cylindrical surface and have no relative velocity with respect to it during their lift. For these reasons, sieving of small particles is possible only when they have some finite relative velocity in respect to cylinder speed. The nature of the motion of compost over the surface of a cylindrical sieve depends upon the coefficient of friction on the given surface; the kinematics operation condition is governed by centripetal acceleration $\omega^{2} r$, the initial conditions of motion of the particles, the point at which they are delivered on to the sieving surface and their initial velocity. Depending upon the relationship among the above factors, the compost in the cylinder may slide along it, separate from its surface and perform a free flight or may move with the surface being at rest relative to it. In the last case the compost material is not sieved (Bosoi et al. 1991). The release of compost (particles) in a cylindrical sieve depends upon their relative velocity and the forces acting on them. These forces are:

- The weight of the particle (mg), directed downward.

- The centrifugal force $\left(\mathrm{m} \omega^{2} \mathrm{r}\right)$.

Where:

$\mathrm{m}$ : The mass of the particle

r: Radius of the cylinder

$\omega$ : Cylindrical sieve angular velocity

The motion of the particle on the cylinder surface is not determined by the tangential forces alone. But, if the resultant of the normal forces $\left(F_{n}\right)$ is not directed towards the cylinder surface, the particle will lose contact with the cylinder.

To find the equations that describe the motion of the particle at a critical speed of the cylindrical sieve (Fig. 2), it can be found that:

- In the normal direction:

$$
\mathrm{Fn}=\mathrm{m} \omega^{2} \mathrm{r}-\mathrm{mg} \sin \alpha
$$

- In the tangential direction:

$m g \cos \alpha=\mu F_{n}$

Where:

$\alpha$ : Angular position of particle on the sieve surface measured from the horizontal axis in the direction of rotation,

$\mu$ : Coefficient of friction between the particle and cylindrical surface.

By substituting $F_{n}$ from equation (1) into equation (2) then: 
$\operatorname{mg} \cos \alpha=\mu\left(m \omega^{2} \mathrm{r}-\mathrm{mg} \sin \alpha\right)$

$\mathrm{g} \cos \alpha=\mu \omega^{2} \mathrm{r}-\mu \mathrm{g} \sin \alpha$

$\mu \omega^{2} \mathrm{r}=\mathrm{g} \cos \alpha+\mu \mathrm{g} \sin \alpha$

$\omega^{2}=\underline{g \cos \alpha+\mu g \sin \alpha}$

$\omega=\sqrt{\frac{g \cos \alpha+\mu g \sin \alpha}{\mu r} .}$

But

$$
\omega=2 \pi \mathrm{N} / 60
$$

So, from equations (5), (6):

$$
N=\frac{60}{2 \pi} \sqrt{\frac{g}{\mu r}(\cos \alpha+\mu \sin \alpha)} .
$$

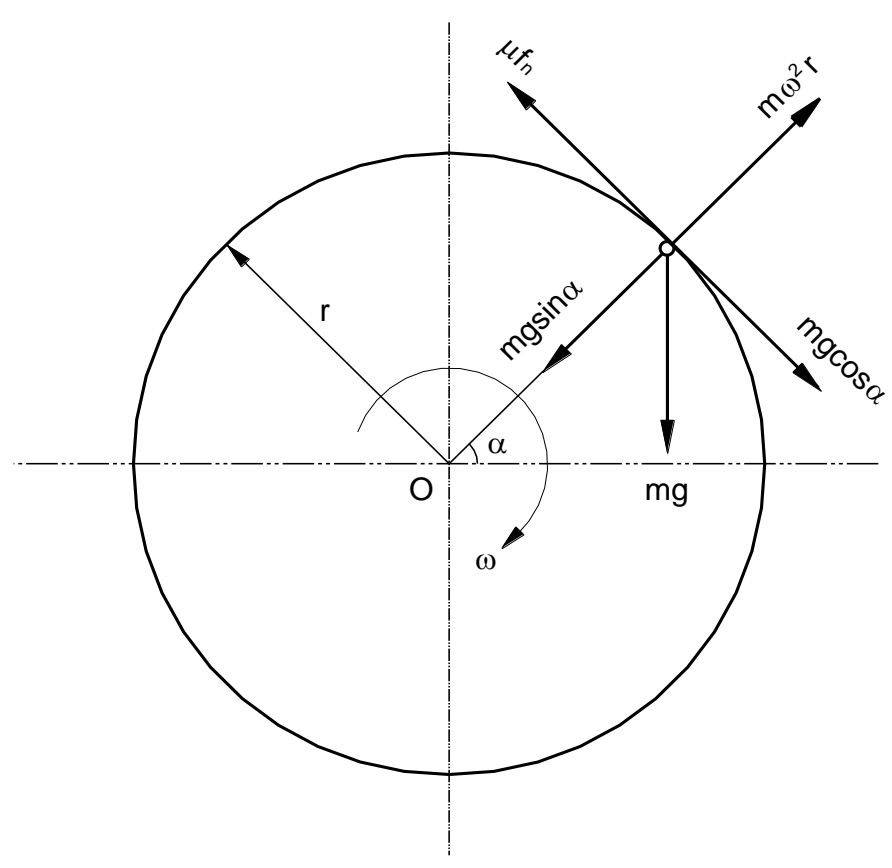

Fig. 2: Forces acting on a particle of compost in a rotating cylinder 
Depending on equations from 1 to 7 , which describe the work of the cylindrical sieve, sieve revolutions number can be estimated as follows: At $\alpha=90$

$$
N=\frac{60}{2 \pi} \sqrt{\frac{g}{r}}
$$

The previous equation shows the number of rotations per minute (critical sieve speed).

The critical speed of the sieve $(\mathrm{N})$ was calculated by substituting the parameter $\{\mathrm{r}$ (cylinder radius $)=80 \mathrm{~cm}\}$ in the previous equation.

The critical speed of the sieve was found to be:

$$
\mathrm{N} \leq 33.5 \sim 34 \mathrm{rpm}
$$

Under this study, the number of revolutions of the sieve should be lower than $34 \mathrm{rpm}$. That is because the particle motion which facilitates the removal of impurities from the compost is due to the relative motion of the compost layers and the axial displacement of the particles. Preexperiments were carried out to find out the optimum sieve speed under the mentioned conditions. Results of these experiments show that separating efficiency will be maximum at sieve speed of $30 \mathrm{rpm}(2.5 \mathrm{~m} / \mathrm{s})$

\subsection{Adjustment of Sieve Inclination Angle}

The sieves are set inclined to the horizontal plane to improve the internal pressure forces during the rotation of the particles mass. According to Klenin et al. (1985), the angle of sieve inclination $(\Theta)$ was selected from the condition:

$$
\Theta \leq \Phi
$$

Where:

$\Phi:$ The friction angle between the compost and the sieve surface.

According to Klenin et al. (1985), the slope angle of the cylindrical sieve on the horizontal plane (sieve inclination angle) should be lower than 27 degrees (to be less than the friction angle between the compost material and the sieve surface). Other pre-experiments were carried out to find out the optimum sieve inclination angle under the previous mentioned conditions. Results of these experiments show that separating efficiency will be maximum at sieve inclination angle of between 10 to 15 degrees. 


\subsection{Experimental Conditions}

The performance of the trommel screen was experimentally measured under the following parameters:

- Four different compost feeding rates $(6,8,10$ and $10 \mathrm{Mg} / \mathrm{h})$.

- Four different compost moisture contents (35, 40, 45 and $50 \%)$.

- Three different screen opening sizes (11, 13 and $16 \mathrm{~mm})$.

\subsection{Measurements and Determinations}

Evaluation of the performance of cleaning machine was based on the following indicators:

\subsubsection{Machine productivity}

Machine productivity was determined by the following equation:

$$
\mathrm{M}_{\mathrm{P}}(M g / h)=\frac{\mathrm{W}_{S}}{\mathrm{t}}
$$

Where:

$\mathrm{M}_{\mathrm{p}}$ : Machine productivity, $\mathrm{Mg} / \mathrm{h}$,

$\mathrm{W}_{\mathrm{S}}$ : Mass of screened compost sample collected from the out let of the screened compost, $\mathrm{Mg}$,

$\mathrm{t}$ : The time consumed to clean the sample, $\mathrm{h}$.

\subsubsection{Separating efficiency}

Separating efficiency was obtained as a percentage between screened compost delivered from the compost output gate and input unscreened compost sample. The percentage of separating efficiency was calculated by using the following equation:

$$
\eta_{\mathrm{S}}(\%)=\frac{\mathrm{W}_{\mathrm{S}}}{\mathrm{W}_{\mathrm{t}}} \times 100
$$

Where:

$\eta_{\mathrm{s}}$ : Separating efficiency, $\%$,

$\mathrm{W}_{\mathrm{t}}$ : Mass of input unscreened compost sample delivered to the cleaning unit, $\mathrm{Mg}$.

\subsubsection{Compost losses percentage}

Compost losses were obtained by collecting the amount of the clean compost which delivered from the outlet gate of both impurities and the un-matured compost. The percentage of compost losses was calculated by using the following equation:

$$
\mathrm{CL}(\%)=\frac{\mathrm{W}_{\mathrm{L}}}{\mathrm{W}_{\mathrm{t}}} \times 100
$$


Where:

CL: Compost losses percentage, $\%$,

$\mathrm{W}_{\mathrm{L}}$ : Mass of the clean compost which delivered from the outlet gate of both impurities and the un matured compost per unit time, Mg.

\subsubsection{Cleaning efficiency}

Cleaning efficiency was obtained as a percentage between the amount of the completely clean compost delivered from the compost output gate and the amount of the screened compost delivered from the same gate. The percentage of cleaning efficiency was calculated by using the following equation (Roth et al, 1975):

Where:

$$
\eta_{C L}(\%)=\frac{\mathrm{W}_{\mathrm{c}}}{\mathrm{Ws}} \times 100
$$

$\eta_{\mathrm{CL}}$ : Cleaning efficiency, \%,

$\mathrm{W}_{\mathrm{C}}$ : Amount of the completely clean compost delivered from the compost output gate

\subsubsection{Required power}

The following formula was used to estimate the required motor power (Kurt, 1979):

$$
\mathrm{P}=\sqrt{3} \times \cos \varphi \times \mathrm{I} \times \mathrm{V} / 1000
$$

Where:

P: Required power, $\mathrm{kW}$,

I: Current intensity, Ampere,

V: Voltage $(380 \mathrm{~V})$, $\cos \varphi=0.7$

\subsubsection{Energy requirements}

The energy requirements for the screening operation can be calculated as follows:

\subsubsection{Criterion cost}

Energy requirements $(\mathrm{kW} . \mathrm{h} / \mathrm{Mg})=\frac{\text { Required power }}{\text { Machine productivity }}$

The criterion cost (L.E./Mg) required for the screening operation was estimated using the following equation (Awady et al, 1982):

Criterion cost $=$ operational cost + compost losses cost

$$
\text { Operational cost }(\mathrm{L} . \mathrm{E} \cdot \mathrm{Mg})=\frac{\text { Machine hourly cost }}{\text { Machine productivity }}
$$


The machine cost (Hourly cost) was determined by using the following equation (Awady et al. 1978):

$$
\mathrm{C}=\frac{\mathrm{p}}{\mathrm{h}}\left(\frac{1}{\mathrm{a}}+\frac{\mathrm{i}}{2}+\mathrm{t}+\mathrm{r}\right)+(\mathrm{W} . \mathrm{e})+\frac{\mathrm{m}}{144}
$$

Where:
C: Machine cost, L.E. /h
P: Price of machine, L.E.
$\mathrm{h}$ : Yearly working hours, $\mathrm{h} / \mathrm{year}$
i: Annual interest rate, \%
a: Life expectancy of the machine, year t: Taxes and over heads ratio, \%
$\mathrm{r}$ : Annual repairs and maintenance ratio, $\% \quad \mathrm{~W}$ :Power of motor, $\mathrm{kW}$
e: Hourly cost, L.E/kW.h m: The monthly average wage, L.E./month 144: Reasonable estimation of monthly working hours.

\section{RESULTS AND DISCUSSION}

The discussion will cover the obtained results under the following heads:

\section{Effect of Some Operating Parameters on Machine Productivity and Separating Efficiency}

Concerning the effect of compost feed rate on both machine productivity and separating efficiency, the obtained results in Fig. (3) show that increasing compost feed rate, under both screen opening sizes of 11 and $13 \mathrm{~mm}$ increased both machine productivity and separating efficiency up to $10 \mathrm{Mg} / \mathrm{h}$, any further increase in compost feed rate up to $12 \mathrm{Mg} / \mathrm{h}$ machine productivity and separating efficiency will decrease. The machine productivity increased by increasing feed rate because of the increase of compost flow on the sieve surface at the same time unit resulting in more separated compost except for the feed rate of $12 \mathrm{Mg} / \mathrm{h}$ due to the high increase in compost losses at high feed rates. This is in agreement with Robert et al. (1992) who stated that smaller openings provide better separation but, for a given screen, reduce the capacity. The same behavior was noticed under screen opening size of $16 \mathrm{~mm}$, results show that both machine productivity and separating efficiency increased under the all experimented feed rates due to the ease motion of compost particles through the wide screen opening of $16 \mathrm{~mm}$ even at high feed rate of $12 \mathrm{Mg} / \mathrm{h}$. As to the effect of compost moisture content on both machine productivity and separating efficiency, results show that increasing compost moisture content, under the all experimented screen opening sizes, increased both machine productivity and separating efficiency up to 

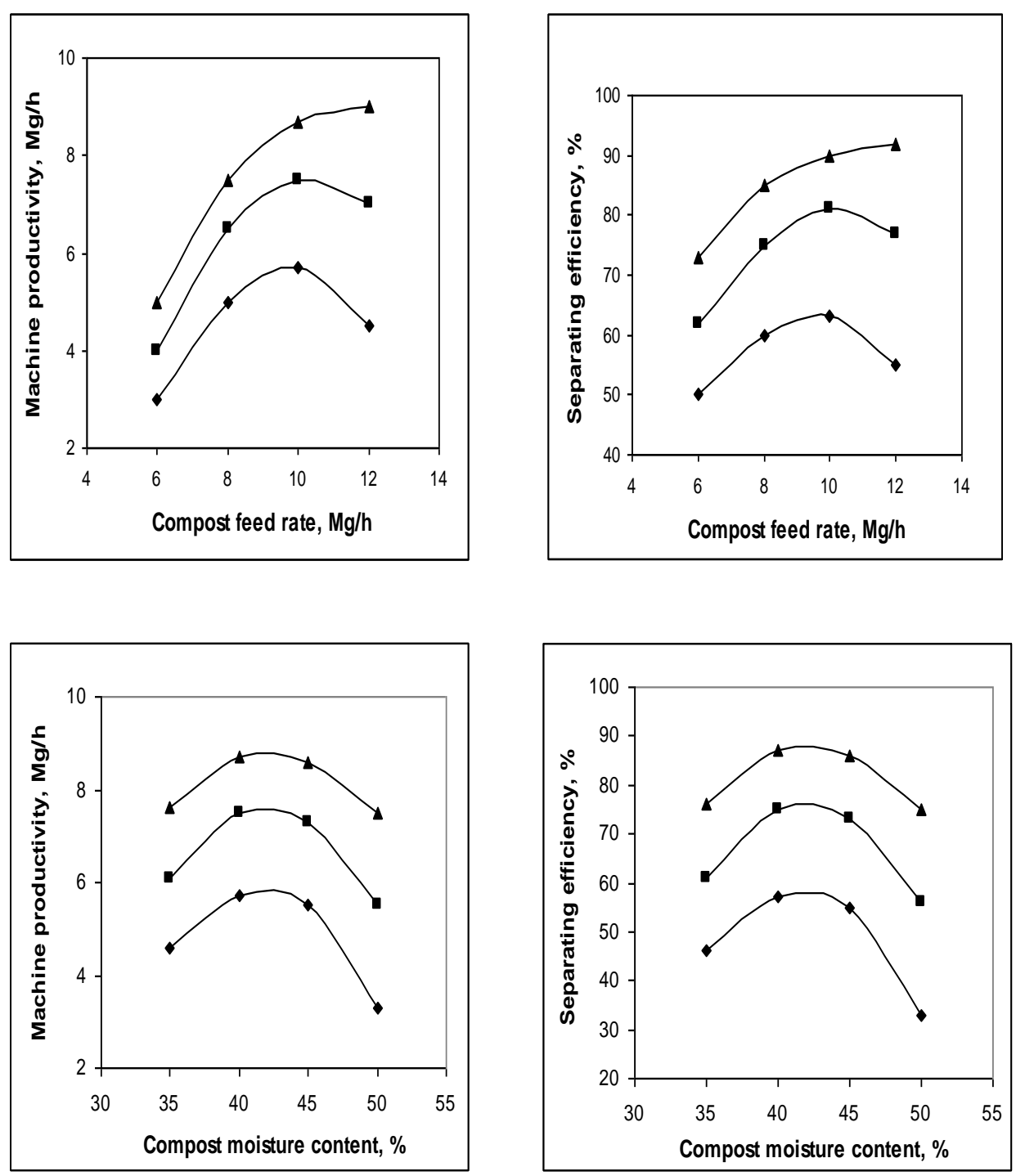

Fig. (3): Effect of some operating parameters on machine productivity and separating efficiency under different screen opening sizes 
$40 \%$. Any further increase in compost moisture content up to $50 \%$ machine productivity as well as separating efficiency will decrease. This is in agreement with Robert et al. (1992) who stated that screens perform better with dryer material (Fig. 3).

\section{Effect of Some Operating Parameters on Compost Losses and} Cleaning Efficiency

Considering the effect of feed rate on both compost losses and cleaning efficiency, the results show that compost losses significantly increased, under the all experimented screen opening sizes, by increasing feed rate. This attributed to the increase of compost thickness on the sieve surface, so most of compost will leave the sieve with impurities from the impurities exit. While the vice versa was noticed with the cleaning efficiency, which decreased by increasing feed rate (Fig.4).

With regard to the effect of screen opening size on both compost losses and cleaning efficiency, the results in Fig.(4) show that compost losses increased while cleaning efficiency decreased by increasing screen opening size. This is in agreement with Robert et al. (1992) who stated that smaller openings provide better separation with high cleaning efficiency comparing with larger one.

As to the effect of compost moisture content on both compost losses and cleaning efficiency, the obtained results show that compost losses vary inversely with compost moisture content. It is clear that compost losses were significantly decreased by increasing compost moisture content up to $40 \%$. Any further increase in compost moisture content up to $50 \%$, compost losses will increase. While, the vice versa was noticed with the cleaning efficiency, which increased by increasing compost moisture content up to $40 \%$, then decreased by the further increase in compost moisture content up to $50 \%$ (Fig. 4).

3. Effect of Some Operating Parameters on Power and Energy Requirements

Concerning to the effect of compost feed rate on power and energy requirements, results in Fig. (5) show that the required power increased by increasing compost feed rate because of the increase of compost flow on the sieve surface at the same time unit which represents extensive load 

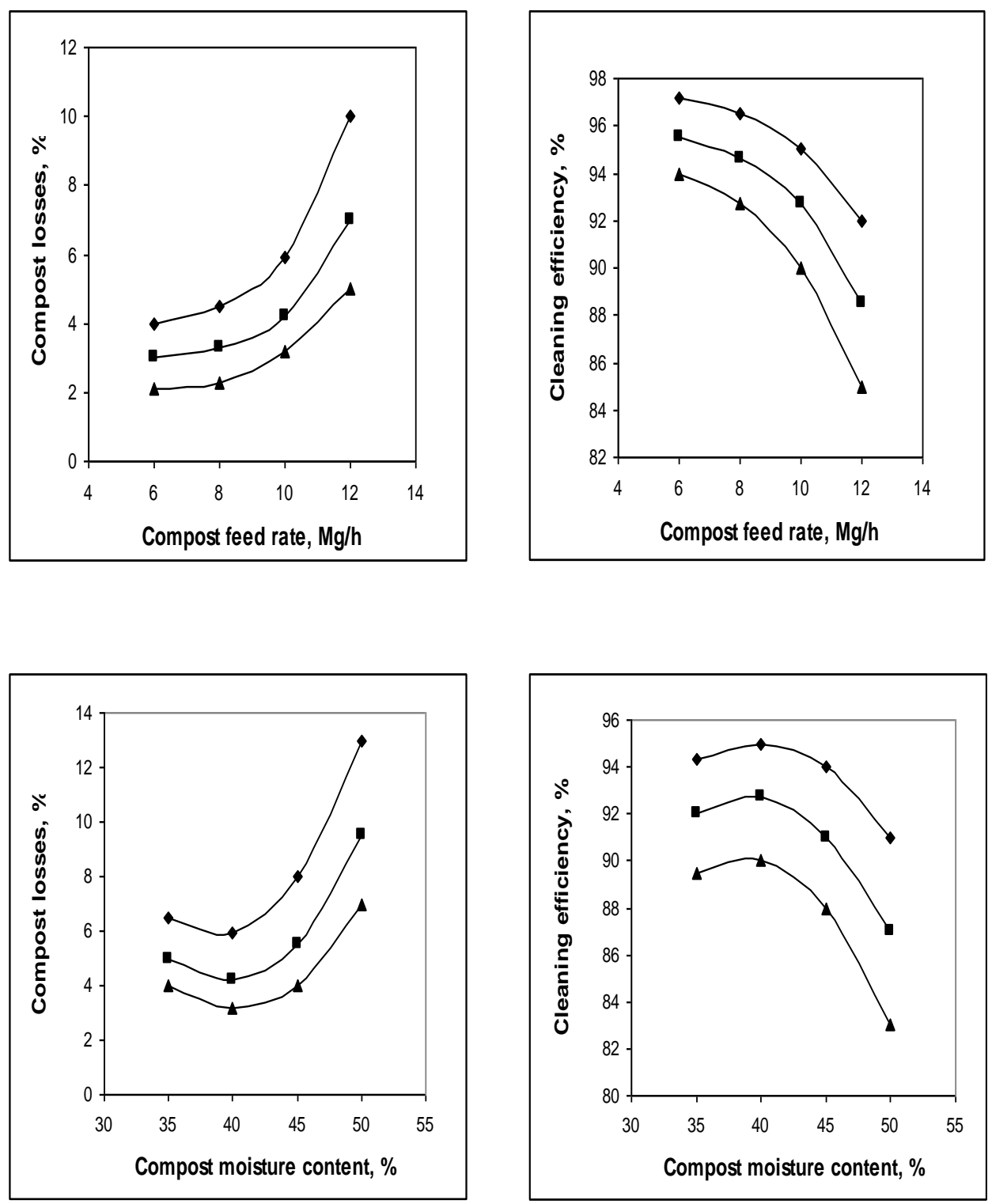

Fig. (4): Effect of some operating parameters on compost losses and cleaning efficiency under different screen opening sizes 

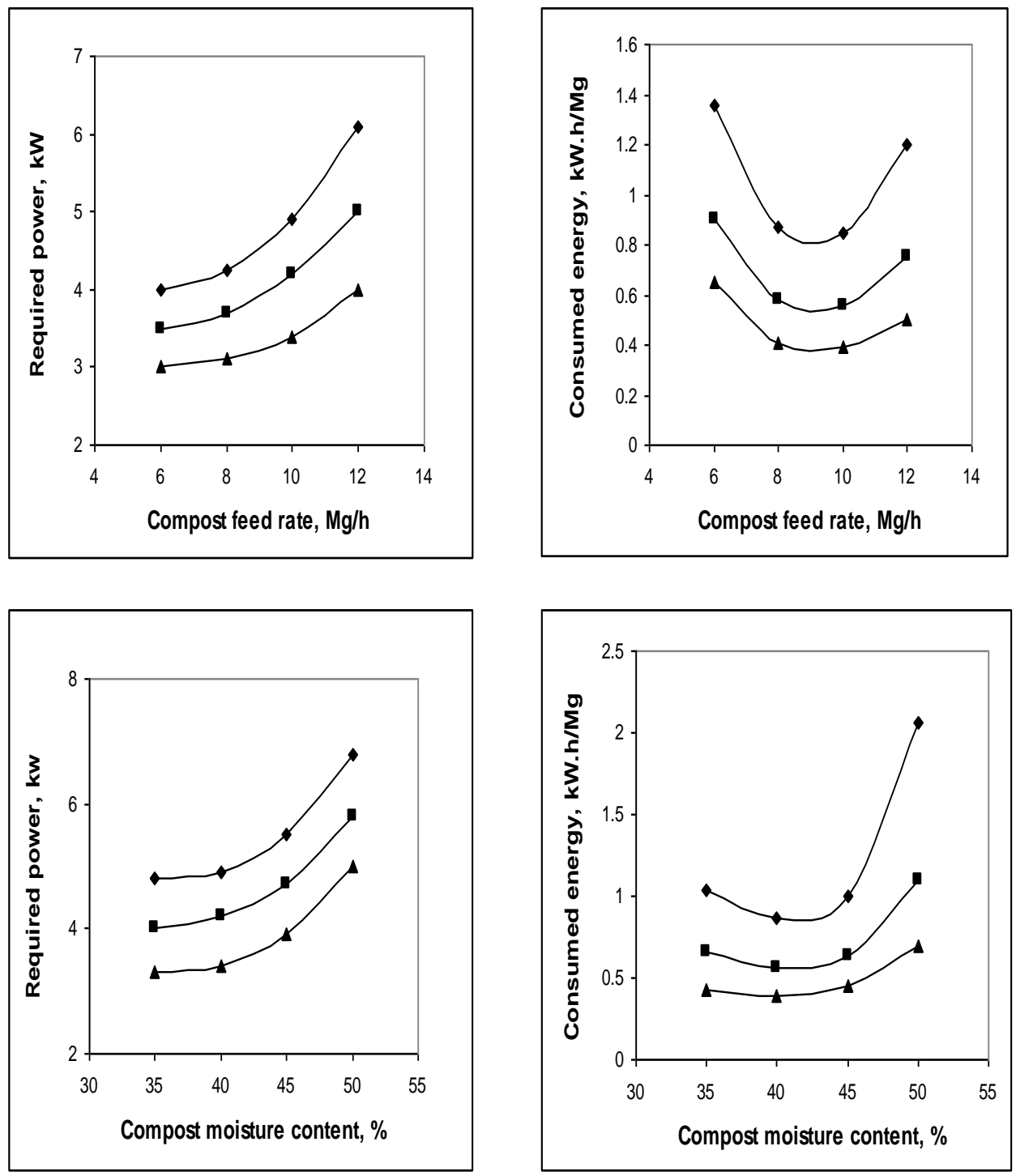

Fig. (5): Effect of some operating parameters on required power and consumed energy under different screen opening sizes 
on the sieve shaft resulting in more power. While, the same data show that the energy requirements vary inversely with feed rate. It is clear that energy requirements were decreased by increasing feed rate up to $10 \mathrm{Mg} / \mathrm{h}$. Any further increase in sieve speed up to $12 \mathrm{Mg} / \mathrm{h}$, energy requirements will increase.

The lower values of feed rate less than the optimum value tend to increase energy due to the decrease in machine productivity. While, the higher values of feed rate more than the optimum value tend to increase energy because of the high increase in the required power comparing with the increase in machine productivity. Regarding the effect of screen opening size on power and energy requirements, results in Fig.(5) show that both power and energy requirements increased by decreasing screen opening size because small opening sizes increase the chances of sieve blinding that reduces machine productivity resulting in high energy requirements.

As to the effect of compost moisture content on power and energy requirements, the obtained results show that increasing compost moisture content increased the required power. The increase in the required power by increasing compost moisture content was due to the excessive load of high moisture content compost on the sieve which consumed more power. While, the same data show that the energy requirements vary inversely with compost moisture content. It is clear that energy requirements were decreased by increasing compost moisture content up to $40 \%$. Any further increase in compost moisture content up to $50 \%$, energy requirements will increase. The lower values of compost moisture content less than the optimum value tend to increase energy due to the decrease in machine productivity. While, the higher values of moisture content more than the optimum value tend to increase energy because of the high increase in the required power comparing with the increase in machine productivity (Fig. 5).

\section{Effect of Some Operating Parameters on Operational and Criterion Costs}

Considering the effect of feed rate on both operational and criterion costs, results obtained show that both operational and criterion costs decreased by increasing compost feed rate from 6 to $10 \mathrm{Mg} / \mathrm{h}$. 

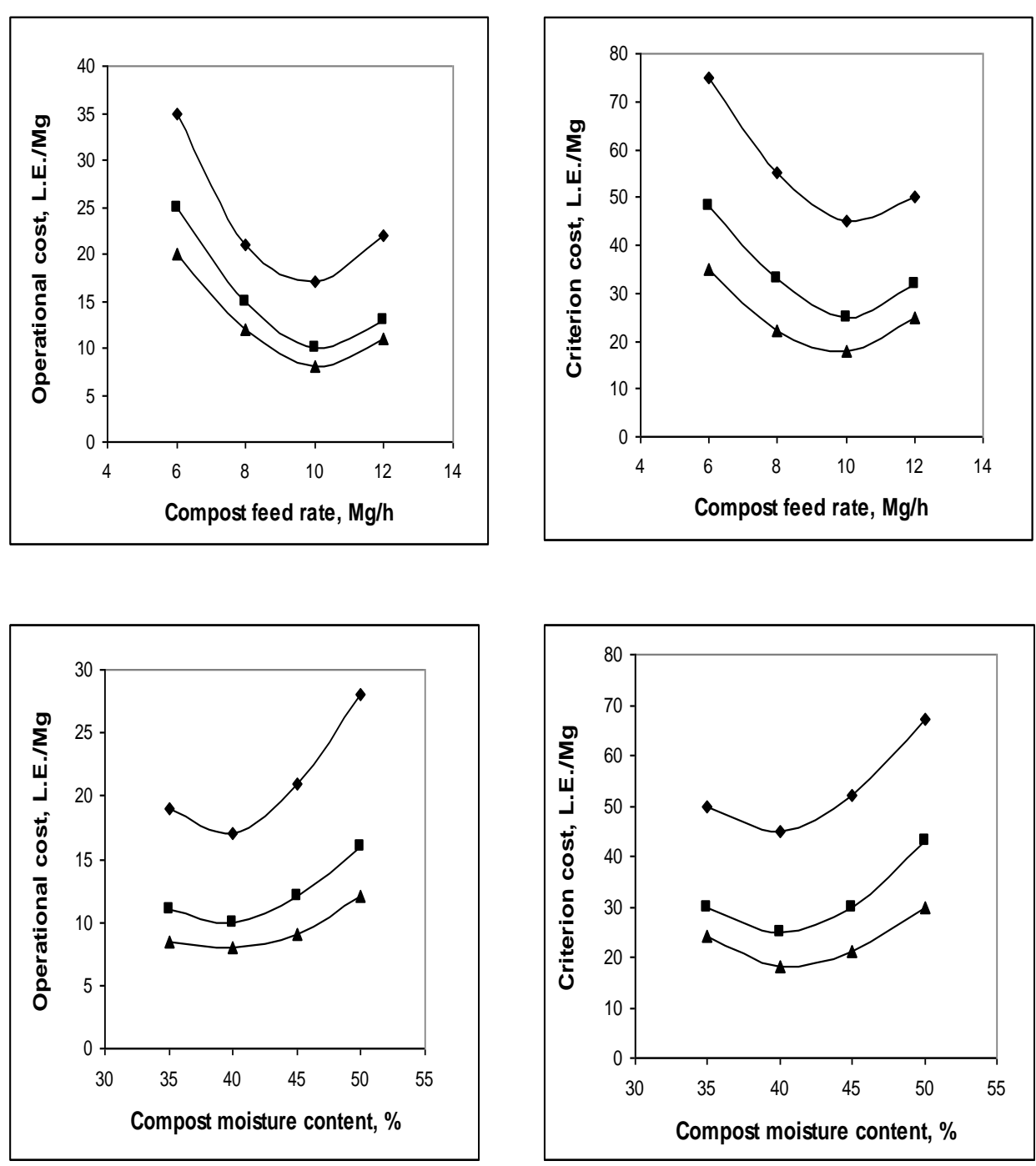

Fig. (6): Effect of some operating parameters on operational and criteria costs under different screen opening sizes

Any further increase in feed rate more than $10 \mathrm{Mg} / \mathrm{h}$ up to $12 \mathrm{Mg} / \mathrm{h}$, operational and criterion costs were found to increase (Fig. 6). The decrease in both operational and criterion costs by increasing compost feed rate up to $10 \mathrm{Mg} / \mathrm{h}$ is attributed to the increase in machine 
productivity. While, the increase in operational cost by increasing feed rate more than $10 \mathrm{Mg} / \mathrm{h}$ is because the rate of increase in hourly cost is higher than the rate of increase in machine productivity. Moreover the increase in criterion cost by increasing feed rate more than $10 \mathrm{Mg} / \mathrm{h}$ is because of the high increase in compost losses. On the other hand, regarding the effect of compost moisture content on both operational and criterion costs, results obtained show that increasing compost moisture content decreased both operational and criterion costs up to $40 \%$, any further increase in compost moisture content up to $50 \%$, operational and criterion costs will increase (Fig. 6). Criterion cost was found to be minimum at compost moisture content of $40 \%$ due to the optimum required power and reasonable amount of compost losses at the above mentioned moisture content.

\section{CONCLUSIONS}

The experimental results reveal that compost losses as well as criterion costs were minimum while, separating and cleaning efficiencies were maximum under the following conditions:

- Operate the trommel screen at a sieve speed of $30 \mathrm{rpm}(2.5 \mathrm{~m} / \mathrm{s})$.

- The slope angle of the cylindrical sieve on the horizontal plane (Sieve inclination angle) should be lower than 27 degrees.

- The screen opening size should be of about $13 \mathrm{~mm}$.

- Clean compost at a moisture content of about $40 \%$.

- Operate the trommel screen at an average feed rate of $10 \mathrm{Mg} / \mathrm{h}$.

\section{REFERENCES}

Awady, M. N. (1978). Tractor and farm machinery. Txt bk., Col. Agric., Ain Shams Uinv.: 146-167.

Awady, M. N; E. Y. Ghoneim and A. I. Hashish (1982). Asritical comparison between wheat combine harvesters under Egyptian conditions. R. S. No.1920, Ain-Shams Univ. Food and Agriculture Organization ( FAO). 
Bosoi, E. S; O. V. Verniaev, I. I. Smimov and E. G. Sultan-Shakh (1991). Theory construction and calculations of agricultural machines. Vol.(2), Mec. Pub., Moscow.

Klenin, N. I; I. F. Popov and V. A. Sakon (1985). Agricultural machines. Theory of operation, computation of controlling parameters and the conditions of operation. Amerind publishing Co. PVT. Ltd., New Delhi.

Kurt, G. (1979). Engineering formulas. Third Ed. Mc Graw-Hill book Company. New York St. Lous San Francisco Montreal-Toronto.

Mariam, M. M; A. F. Abdel Mottaleb, A. A. Derbala and T. Z. Fouda (2010). Basic requirements for the design and construction of a local compost screening unit. Misr J. Agric. Eng. 27(4): 2059-2085.

Mariam, M. M; A. F. Abdel Mottaleb, A. A. Derbala and T. Z. Fouda (2011). Manufacture and performance evaluation of a local compost screening unit for maximum product quality. Misr J. Agric. Eng. 28(2): 538-555.

Morad, M. M; A. F. Abdel Mottaleb and T. Z. Fouda (2008). Manufacture and performance evaluation of a self-propelled compost turning machine. Misr J. Agric. Eng. 25(4): 1478-1492.

Page, N; J. Leonard and G. Clark (2005). Comparison of screening methods to refine MSW compost . Alberta Environment, Edmonton, Canada. Bio-cycle, 46(4): 57-58.

Robert, R; K. Maarten, B. W. George, E. S. Mark, L. R. Tom, J. K. John, R. G. Francis, L. J. Lucien, K. David, W. M. Dennis, A. J. Harry and F. B. William (1992). On-farm composting handbook. Northeast Regional Agricultural Engineering Service, 152 KileyRobb Hall, Cooperative Extension, Ithaca, NY 14853-5701, USA.

Roth, L. O; F. R. Crow and G. W. A. Mahoney (1975). An introduction to agricultural engineering. The AVI Pub. Co., Inc., West Port Conn.

William F. B. (2000). Compost quality standards \& guidelines. New York State Association of Recyclers. Woods End Research Laboratory, Inc. P: $1-42$. 


\section{الملخص العربي \\ تعيين القيم المثلى لعوامل تشغيل آلة غربلة وتنظيف الكمبوست}

أ.د. محمد محمد مر اد حسن* د. هند أحمد مجدى المغاوري ** د. كمال إبراهيم وصفى أحمد** ه

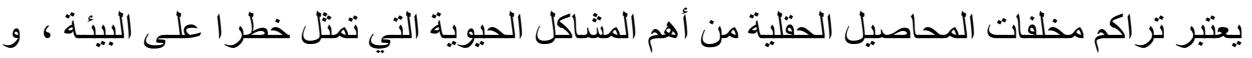

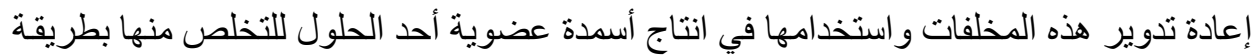

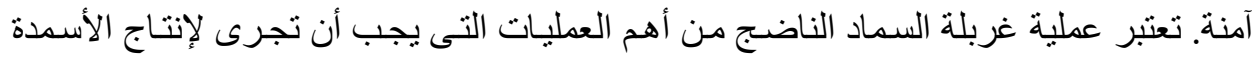

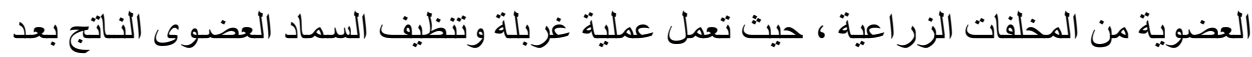
النضج من الثوائب على رفع جودة المنتج وتعمل على رفع سعر تسويقه. لذا فقد اتجه هذا البحث الى محاولة القاء الضوء على احدى معدات غربلـة وتتظيف الكمبوست بغرض رفع جودة المنتج النهائى.

تم اجر اء تحليلات نظرية فى محاولة للتنبؤ بالقيم المثلى لكل مـن سـر عة غربـال التنظيف وز اويـة التها ميل الغربال على الأفقي ، وكذلك تم اجر اء تجارب لتحديد القيم المثلى لعو امل التشغيل معدل

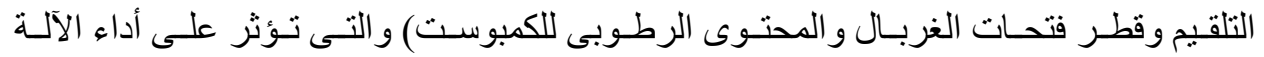

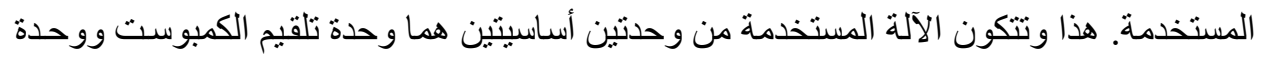
الغربلة و التنظيف.

تم تتفيذ التجارب العملية بشركة سوبر بايو للأسمدة العضوية بمحافظة الدقهلية خلال عامى

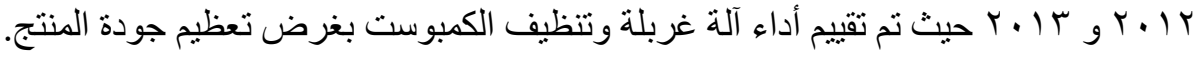
أظهرت النتائج التجريبية أن كل من فواقد الكمبوست والتكاليف الكلية تكون فى أدنى قيمها وأن كفاءة التنظيف تكون أعلى ما يمكن تحت ظروف التشغيل الآتية:

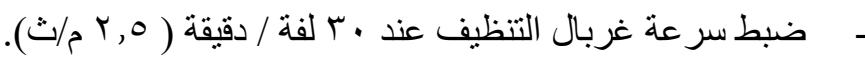
- - يجب ألا تزيد زاوية ميل الغربال أثناء التشغيل عن V د درجة. - يجب أن تكون فتحات الغربال بقطر سا مم. - غربلة وتنظيف الكمبوست عند نسبة رطوبة حوالى • ع \%. - ضبط معدل تلقيم الكمبوست عند ـا ميجاجر ام/ساعة.

* أستاذ ورئيس قسم الهندسة الزراعية ـ كلية الزراعة - جامعة الزقازيق. * مدرس بقسم الهندسة الزراعية ـ كلية الزراعة - جامعة الزية الزقازيقة 